\title{
Security and devolution in Kenya: Struggles in applying constitutional provisions to local politics
}

\author{
Dominic Burbidge*
}

\begin{abstract}
The Fourth Schedule of the Constitution of Kenya (2010 Constitution) retains security as a function of National Government. At the same time, the 2010 Constitution creates 47 county governments with considerable autonomy in public service provision. Many county governors have demanded a say in the deployment of security services because of the inequality of security provision throughout Kenya's history. While the 2010 Constitution is clear, however, in not providing much of a local say in the way security is deployed, it is found that in their day-to-day activities security officials depend on a close relationship with local politicians. This article examines constitutional provisions in the context of the history of security in Kenya and its practical deployment under the new political framework. It is argued that the long-term reasons for the inconsistent and insensitive use of security forces endure in contemporary dilemmas over the relationship between national security provision and local politics. Regardless of what the 2010 Constitution says, successful deployment of security depends on cooperative local political relations. Attempts to establish these links can often lead county governors to overstep their mandates, however, contravening the 2010 Constitution. We are therefore not only witnessing a transformation of the political structure through devolution but also transformation of the negotiated structure of security's deployment.
\end{abstract}

* $\quad$ BSc (QMUL), MPhil (Oxford), DPhil (Oxford) 


\section{Introduction}

When in 1919 Max Weber defined the state as 'a human community that (successfully) claims the monopoly of the legitimate use of physical force within a given territory ${ }^{1}$ he set off an appreciation of the security apparatus as a central quality for defining statehood. In line with his thinking, we do not only look for how much force a state can exercise but also how legitimately and where. A central informant on this question is a state's constitution, which describes the way in which state power can be deployed legitimately. Constitutions are somewhat unique in advancing a claim to boundedpower: sovereignty is simultaneously described as qualified and unqualifiable. As such, there is an interdependent relationship between a constitution and its security apparatus, which allows for no history of a first mover. Legal theory must therefore accept that the state's constitution and the state's Constitution are inextricably bound, just as the law is in part made valid through the efficacy of its implementation. ${ }^{2}$ Discussing how security is administered is therefore in part a discussion of what and where the state is.

Kenya has a political history particularly bound to notions of state sovereignty through securitisation. While some justification for this fixation can be found in the state's contemporary confrontation with terrorism, ${ }^{3}$ or the dangerously mismanaged border with Somalia, ${ }^{4}$ the predilection stems in its origin from the Mau Mau crisis, which led to a state of emergency from 1952 to $1960 .^{5}$ The Mau Mau uprising was a Kikuyu rebellion against conformity to colonial restrictions on land ownership, freedom of movement and freedom to decide one's own affairs. ${ }^{6}$ Because the Kikuyu heartlands were close to if not overlapping with settler territories, the uprising's violence constituted a credible threat to settler livelihoods, provoking in turn considerable reactionary aggression from colonial security services. In terms of its comparative effect on the nature of statehood

\footnotetext{
Weber M, 'Politics as a vocation', Free Students Union of Bavaria, Munich, 28 January 1919, 1 (emphasis in original).

2 Kelsen H, General theory of law and state, Harvard University Press, Cambridge, MA, 1945.

3 Bachmann J and Hönke J, "Peace and security” as counterterrorism? The political effects of liberal interventions in Kenya', 109 African Affairs, 434, 2010, 97-114; Burbidge D, 'The Kenyan State's fear of Somali identity', Conflict Trends, 2, 2015.

4 Thompson VB, Conflict in the Horn of Africa: The Kenya-Somalia border problem, 1941-2014, University Press of America, Lanhan, MD, 2015.

5 See Anderson D, Histories of the hanged: Britain's dirty war in Kenya and the end of Empire, Phoenix, London, 2005; Bennett H, Fighting the Mau Mau: The British army and counter-insurgency in the Kenya emergency, Cambridge University Press, Cambridge, 2013.

6 Hobson F, 'Freedom as moral agency: Wiathi and Mau Mau in colonial Kenya', 2 Journal of Eastern African Studies, 3, 2008, 456-470.
} 
in Kenya, the hardening militarisation of the State shortly before independence paved the way to a larger appetite among public officials for state violence, often of an extrajudicial nature. Kenya has always struggled, therefore, with demarcation of even and legitimate use of force over a given territory. The dilemma was compounded by reactive reorganisation of the military following the 1982 attempted coup d'état, and by the lack, hitherto, of an effective constitution.

The promulgation of the Constitution of Kenya (2010 Constitution) now provides the clearest outline of how force is deployed legitimately by the Kenyan State. Alongside this, the 2010 Constitution has radically decentralised governance by creating 47 devolved governments that are operating as mini-states across the country. This presents a novel and perplexing new question for the organisation of security services: is the coercive arm of the State able to work with sufficient flexibility given Kenya's local political diversities? This article starts answering this question in part two by providing a historical overview of statehood and security services in Kenya from the colonial era to the present. The section identifies areas of continuity in the dilemmas presently faced, and the deep-rooted nature of some of the challenges. Part three then explains the current legal situation of security provision under the 2010 Constitution, and how national provision of security relates to the 47 county governments. Part four describes and evaluates how this relationship between the centre and periphery is playing out in practice in four key case studies. These case studies show that there is much of importance happening outside the realm of what is considered appropriate according to the 2010 Constitution. Further, due to strong variation in the relationships between local politicians and local security officials, diversities in the performance of security services are emerging. The article then concludes with wider reflections on what these changes mean for the sovereignty of the Kenyan State.

\section{State and security in Kenya: A historical overview}

Across British colonial Africa, emphasis was placed on governance on the cheap. ${ }^{7}$ Africa was the last continent to be colonised, which meant that colonial powers arrived to the scramble having dropped some of the more idealistic notions of developing civilisation, substituting these with a utilitarian evaluation of cost and

As Nugent explains: 'The cardinal principle was that the colonies should pay for themselves.' Nugent

P, 'States and social contracts in Africa', 63 New Left Review, 2010, 35-68, 44. 
benefit. Hannah Arendt notes this change in mental stance among colonial administrators in her description of the rise and subsequent decline of what she calls a generation of 'dragon-slayers'. Dragon-slayers, Arendt describes, 'went enthusiastically into far and curious lands to strange and naive peoples to slay the numerous dragons that had plagued them for centuries. ${ }^{8}$ The self-perceived idea among colonials was that they could rid primitive peoples of irrational attachments and illusions, building instead on natives' supposed fundamental innocence in order to set them on a path of progress and modernity. The earlier, idealistic sentiment of the colonial project - captured well in Robinson Crusoe's attitude towards the native he names Friday' - legitimised colonials to, 'change from the obedient underling of one of His Majesty's soldiers into an exciting and noble figure in the natives' world, a well-beloved protector of the weak, the dragon-slayer of old tales. ${ }^{10}$ The very distinction between the old and new world, between the metropole and the colony, is premised on the idea that 'the normal rules of peace and war were suspended beyond a certain imaginary line ${ }^{\text {s1 }}$ - for the Americas the line was somewhere in the mid-Atlantic; for Africa, at the limit of previous Roman reach.

As the colonial project progressed, the dragon-slayer evolved into two quite distinct professional traditions: the first, the bureaucrat, who took a more hardnosed approach to civilisation as fundamentally a project of law and order; and the second, the secret agent, who played 'the Great Game of endless ulterior motives in an endless movement' and 'preferred serving mysterious forces all over the world to serving the common good of their country. ${ }^{12}$ It is at the juncture of this latter bifurcation of the colonial mission that the scramble for Africa took place, which meant the ambition to build long-lasting and durable state institutions, was comparatively absent. The African colonial project attempted, rather, a modicum of state administration through recourse to 1) detached law and order bureaucracy, while 2) valuing Africa in terms of the Great Game of imperial expansion. Because these two commitments ditched notions of the common good, the justification for law and coercion became purposeless, resting instead

Arendt $\mathrm{H}$, The origins of totalitarianism, The World Publishing Company, Cleveland, OH, 1958, 209-10. Crusoe reflects on his relationship with the newfound native: 'Besides the pleasure of talking to him, I had a singular satisfaction in the fellow himself: his simple, unfeigned honesty appeared to me more and more every day, and I began really to love the creature; and on his side I believe he loved me more than it was possible for him ever to love anything before.' Defoe D, Life and adventures of Robinson Crusoe, Albert Cogswell, New York, 1880 [1719], 179.

10 Arendt, The origins of totalitarianism, 210.

11 Johnson P, A bistory of the American people, HarperCollins Publishers, New York, NY, 1997, 17.

12 Arendt, The origins of totalitarianism, 221. 
on simplified notions of cost versus benefit - with the cost being the manpower and investment required for suppression, and the possible benefits including tax collection, forced labour, resource extraction, prevention of access to other colonial powers, and territory as future bargaining chip. Africa equals law minus common good.

To ensure colonial Africa was governed on the cheap, British authorities developed a system of indirect rule that utilised local chieftaincies as indigenous representatives of the State for local areas. This best met the dual commitment to law and expansion, because it meant the justice administered to newly acquired territories did not need to conform to either the metropole or other colonial possessions. The downside, however, was that travelling through British colonial Africa was like travelling through a patchwork quilt of different rules and norms, oftentimes irreconcilable. Mahmood Mamdani argues this to have constituted a new kind of judicial governance:

Just as the colonial state usurped the erstwhile right of the people or the peers to destool an errant chief, so it now replaced the village council with the administratively appointed village chief as the local tribunal. The impact of this shift was enormous. For nowhere in Africa did there exist centralized judicial institutions with exclusive jurisdiction over an area, something that colonialism created as customary. ${ }^{13}$

The key illustration of this in Kenya was the promulgation of the Native Courts Ordinance in 1907, which established native tribunals with the intention of serving each of Kenya's ethnic groups. ${ }^{14}$ The relationship between native tribunals and the British courts was specified by the Kenyan Native Tribunal Ordinance in 1930, which 'empowered the Governor or Provincial Commissioner to establish native tribunals with jurisdiction limited to civil matters and certain categories of criminal matters relating to natives and consenting Arabs. ${ }^{15}$ The general idea complied loosely with the distinction between criminal and civil law, with British colonialism in Africa seeking greater standardisation of law across territories for severe criminal cases that carried the death sentence or life imprisonment, ${ }^{16}$ and suspending the application of customary law if the outcome was deemed repugnant to justice and morality. ${ }^{17}$ This latter criterion

13 Mamdani M, Citizen and subject: Contemporary Africa and the legacy of late colonialism, Princeton University Press, Princeton, 1996, 48.

14 The Judiciary, 'Our history', http://www.judiciary.go.ke/portal/page/our-history.

15 Ibhawoh B, Imperial justice: Africans in empire's court, Oxford University Press, Oxford, 2013, 87.

16 Ibhawoh, Imperial justice.

17 Kariuki F, 'Customary law jurisprudence from Kenyan courts: Implications for traditional justice systems’, Working Paper, Strathmore University, 2015, 1-13, 3. 
proved extremely vague, with historian David Anderson arguing that the clauses amounted to 'an effective "loosening" of the strictures of court procedure."18

Despite allowing room for local norms and customs in civil matters, the frequent overlap in jurisdiction between native tribunals and British courts threatened rule of law. The failure to genuinely learn and communicate tribal norms, histories, and jurisprudences meant the implementation of customary law became increasingly beholden to local powerbrokers and weighted against newcomers from different ethnic communities. ${ }^{19}$ A rupture emerged between colonial administrators who appreciated local customs and those who instead prioritised formalised and transferable legal procedures through standardised law: their debate culminating in something of a 'dialogue of the deaf'. ${ }^{20}$ Perhaps because of the growing arbitrariness of defining what counted as customary, in 1963, Kenya's Independence Constitution abolished unwritten customary crimes. ${ }^{21}$ The manoeuvre accepted in method of jurisprudential articulation what was already present in the structure of colonial authority: primacy of legal-bureaucratic centralism.

Such divisive notions of jurisdiction had profound effect for the development of policing. As David Killingray explains:

The institutions of indirect rule, and the extension of this system throughout much of British Africa in the 1920s and 1930s, emphasized the role of chiefly authority in preserving law and order. Government police and soldiers existed, often at a distance, for use in cases of real emergency when local unrest might precipitate a threat to the continued rule of African agents of the colonial state, and, more seriously, to the security of the colonial order itself. For the most part the daily maintenance of normal law and order was in the hands of African 'traditional' rulers and the agencies that they employed. ${ }^{22}$

For some African colonial territories, such as Kenya, the presence of permanent white settlers meant colonial authorities felt less inclined to leave policing in the hands of local chiefs. The coercive apparatus of the state was therefore reshaped to meet two distinct needs: the first in keeping with the ongoing trend

18 Anderson D, 'Policing, prosecution and the law in colonial Kenya, c. 1905-39'. Ch 11 in Anderson D and Killingray D (eds), Policing the empire: Government, authority and control, 1830-1940, Manchester University Press, Manchester, 1991, 190.

19 Parsons T, 'Being Kikuyu in Meru: Challenging the tribal geography of colonial Kenya', 53 Journal of African History, 1, 2012, 65-86, 82.

20 Anderson, 'Policing, prosecution and the law in colonial Kenya', 191.

${ }_{21}$ Kariuki, 'Customary law jurisprudence from Kenyan courts', 5.

22 Killingray D, 'The maintenance of law and order in British colonial Africa', 85 African Affairs, 340, 1986, 411-437, 416. 
of governance on the cheap, and the second in social contract with the settler population, seeking to meet their needs in a manner akin to the government back home. The latter was of course biased towards white settler welfare, and magnified the already inconsistent approach to law by the colonial state. John Ambani and Ochieng Ahaya make the interesting additional argument that the divisions of race which the colonial episode sparked have continued among Kenyan judges to this day by way of class divisions, given the economically privileged circles that highly educated Kenyans tend to move in, distancing them from local customs. ${ }^{23}$ The criticism meets with descriptions of the race dimension regarding taxation in Kenya, which saw an easy shift from race to class after independence when high-earning Africans joined whites and Asians to become subject to income tax, seamlessly becoming the main group for the State to then satisfy through tax concessions. ${ }^{24}$

For police administration, the presence of white settlers caused all manner of discrimination in the management of law and order. The concerns of settlers were of course privileged, and yet there was also difficulty in pursuing criminals outside the 'White Highlands' into districts covered by the tribal police. As Anderson quips, '[u]nfortunately, criminals did not always restrict their activities to the jurisdiction of a single police force. ${ }^{25}$ Under the Mau Mau uprising, these bureaucratic niceties were swept aside, however, and Kenya became akin to a 'security state, ${ }^{26}$ with detailed regulation of the movement of Africans. In the storm of the crisis, many Kenyans were swept into camps as suspects and tortured to give information, ${ }^{27}$ blurring the distinction between who was a bystander and who actively involved in Mau Mau. Explaining this kind of trend across colonial Africa, Paul Nugent analyses that ' $[a]$ rule of thumb that is broadly valid is that colonial violence was inversely proportional to the level of effective bureaucratic control. $^{28}$

To simply give the impression of growing centralisation of security in Kenya over the colonial period would be to ignore, however, the differentiated nature of policing. As Killingray explains, throughout British colonial Africa

\footnotetext{
23 Ambani JO and Ahaya O, 'The wretched African traditionalists in Kenya: The challenges and prospects of customary law in the new constitutional era', 1 Strathmore Law Journal, 1, 2015, 41-58.

24 Prichard W, Taxation, responsiveness and accountability in sub-saharan Africa: The dynamics of tax bargaining, Cambridge University Press, Cambridge, 2015, 121.

25 Anderson, 'Policing, prosecution and the law in colonial Kenya', 187.

26 Killingray, 'The maintenance of law and order in British colonial Africa', 436.

27 Anderson, 'Policing, prosecution and the law in colonial Kenya'.

28 Nugent, 'States and social contracts in Africa', 44.
} 
'many territories had different branches of the police: town police employed by municipalities and often largely concerned with regulating African movements within the town, and other police units charged with specific duties involving the escort of officials and specie, or supervising the railways, mines and waterways. ${ }^{29}$ The distinction between types of police in Kenya follows from this trend. Currently Kenya hosts three clearly separate types of police: the General Service Unit (GSU) (previously General Purpose Unit (GPU)), the Administration Police (previously Tribal Police), and the Regular Police. ${ }^{30}$

Why three different police forces? To keep things cheap, British colonials restricted the deployment of police to rural areas and instead fostered a central force to intervene in cases of emergency only. The GSU is thus paramilitary, and tends to use coercion more liberally, and to seek immediate restoration of order rather than finding concord with communities. The late colonial period exacerbated these trends, with Killingray noting how the then GPU in Kenya had greatly expanded by independence. ${ }^{31}$ Because the aim was to develop an authoritative force that could move in and out of local communities at speed, police officers were expressly chosen to be members of ethnic groups from faraway places, with fewer loyalties to their likely places of deployment. Thus the police in Kenya were first mainly Nubians, followed only later by Kamba, Kalenjin and Ganda. ${ }^{32}$ The trend is still apparent in discussing present-day Kenyan security reform, where it is sometimes taken for granted that so long as a county commissioner is not of the ethnicity of any local groups; s/he will be able to act as conflict mediator, because impartial.

The tribeless colonials demanded a police force reflective of their position, and so reached out to the edges of the empire to those thought different, like them, to the local population. The impartiality paradigm of colonial thinking treats police as at their best the less they know about their local area, in turn ruining state-society trust. Mark Neocleous adds to this view of the police by means of the argument that pacification was and is a prerequisite to indiscriminate economic exploitation. ${ }^{33}$ On his account, policing tends to take the form of a manhunt whereby the key distinction of interest to the state is who is produc-

\footnotetext{
29 Killingray, 'The maintenance of law and order in British colonial Africa', 414.

30 While these are the main formations within the police service in Kenya, there are others dealing with special security concerns such as cattle rustling, and tourism.

Killingray, 'The maintenance of law and order in British colonial Africa', 422.

Killingray, 'The maintenance of law and order in British colonial Africa', 425.

Neocleous M, 'The dream of pacification: Accumulation, class war, and the hunt', 9 The Journal of the Society for Socialist Studies, 2, 2013, 7-31, 15-7.
} 
tive and who unproductive: the latter are those the police are tasked with pacifying in order to facilitate economic expansion. ${ }^{34}$ Although an attractive argument, Neocleous fails to identify the inherent tension between development by means of ever-inclusive capitalist dynamics (a Marxist perspective) and colonialism as government on the cheap (which does not see productivity payoffs in pacifying rural areas far from the settler population). Order per se was the colonial police priority, executed at most in tandem with, rather than led by, opportunities for enhancing labour productivity.

A centre-periphery framework is nevertheless helpful for identifying continuity in Kenya between state provision of security in colonial and independence eras. Independent Kenya kept the graded distinctions in types of police, and continued to redeploy the more centralised arms of the State to protect the interests of the upper classes, leaving areas of the country considered less important by the elites almost entirely without state presence. Perhaps an extreme example, the Ilemi Triangle at the tip of Kenya's northwest has been disputed between Kenya and Sudan (now South Sudan), in part because the area went many years without either country extending their state administration to the region. The most significant political intervention - before the discovery of oil - came through the funding of local community militias (by Kenya, Ethiopia and Sudan, in turn) to engage in proxy wars over ownership. ${ }^{35}$ Similarly, the phenomenon of cattle rustling continues almost unabated in Kenya's north, having become only more intense with the greater availability of small arms. Karen Witsenburg and Adano Wario assess whether this is due to climate change causing greater scarcity but find that, in fact, cattle raiding tends to occur during wet seasons, suggesting the raids are opportunistic rather than out of necessity. ${ }^{36}$ All this invites the question: why have police in Kenya failed to make in-roads into rural crime? On Bruce Baker's reading, '[ $\mathrm{f}$ ] or those living in rural areas and townships [in Africa], it is not just that the State police are ineffective, predatory and potentially violent; they are absent. ${ }^{37}$ On the specific problem of cattle rustling, he explains:

Among the cattle herders of East Africa, informal security groups have a long tradition. Cattle raiding is dealt with by pursuit and recapture by posses, together with the summary

\footnotetext{
34 Neocleous M, 'The dream of pacification: Accumulation, class war, and the hunt', 7-31, 15-7.

35 Menas Borders, 'The Ilemi Triangle sovereigntyscapes (Part Two)' (Dec 2010). http://www.menasborders.com/documents/MB_ilemi_pt2.pdf, 3.

36 Witsenburg KM and Adano WR, 'Of rain and raids: Violent livestock raiding in northern Kenya', 11 Civil Wars, 4, 2009, 514-538.

37 Baker B, 'Protection from crime: What is on offer for Africans?' 22 Journal of Contemporary African Studies, 2 2004, 165-188, 165.
} 
killing of those deemed responsible. Since state policing in Uganda, Kenya and Tanzania has never been able to prevent cattle raiding or bring the perpetrators to justice, the old violent retaliatory raids have continued. ${ }^{38}$

In 2012, northern Kenya witnessed the 'worst single incident for Kenyan police in living memory ${ }^{39}$ when 42 police officers were killed as they attempted to recover Samburu cattle from the Turkana in Baragoi. ${ }^{40}$ The incident highlights the weakness of the State at the periphery, something that has unfortunately proved a hallmark of sub-Saharan governments. ${ }^{41}$

In terms of latest trends, analysts concerned with security in Kenya have highlighted how failures in security provision have produced a vacuum being filled by other means. Such occurrences are by no means new, with David Throup writing that in the period 1947-54 colonial authorities abandoned interest in nonsettler areas of Nairobi, leaving local affairs 'to the control of the political militants and their allies among the Kikuyu-dominated street gangs which terrorized the Luo and Abaluhya inhabitants of the city. ${ }^{42}$ Nairobi, though the centre of Kenyan State administration is by no means out of the dock on this historical trend, evidenced by well-documented contemporary analysis of the role the Mungiki gang plays in creating extortion rackets within the city. ${ }^{43}$ The strength of Mungiki grew to the extent that it was co-opted, rather than battled, by the political establishment, and used in furthering post-election violence following the 2007 elections. However, the strength of the State seemed to regain with the more decisive victory of Uhuru Kenyatta in the 2013 elections, which coincided unsettlingly with sudden elimination of key Mungiki associates. ${ }^{44}$

Alongside the various swellings and containments of informal vigilante groups in Kenya, the country has witnessed an enormous privatisation of the security sector. Abrahamsen and Williams conduct a review of the changing landscape of security provision and diagnose that ' $[\mathrm{b}]$ oth the rise in crime and the

\footnotetext{
38 Baker, 'Protection from crime', 174.

39 McKenzie D and Leposo L, 'Police: 38 Kenyan officers killed in ambush involving cattle rustlers', CNN, 13 Nov 2012.

40 Amnesty International, 'Police reform in Kenya: "A drop in the ocean", Amnesty International Publications, London (2013), 24; McKenzie \& Leposo, 2012.

41 Herbst J, States and power in Africa: Comparative lessons in authority and control, Princeton University Press, Princeton, 2000.

42 Killingray, 'The maintenance of law and order in British colonial Africa', 418.

43 Anderson D, 'Vigilantes, violence and the politics of public order in Kenya', 101 African Affairs, 405, 2002, 531-555.

44 Mueller SD, 'Kenya and the International Criminal Court (ICC): Politics, the election and the law', 8 Journal of Eastern African Studies, 1, 2014, 25-42.
} 
growth of the private security sector in Kenya are intimately connected to the erosion of state capacities and services that began in the late 1980s and continued throughout the 1990s. ${ }^{245}$ The trend is consistent with Christopher Clapham's continent-wide analysis, which makes the argument that there is no genuine public police in Africa 'in the sense of security systems that protect all citizens without discrimination', because security systems 'have been developed to support the ruling elite in their hold on power and wealth. ${ }^{46}$ However, describing security as increasingly privatised is more complicated than simply saying it fails to serve a public role. Because security is a public good - economically speaking - its private provision can nevertheless have an unintended public effect of making crime and the breaking of law generally less attractive. Weighing up the pros and cons, Rita Abrahamsen and Michael Williams write:

Given adequate level of co-operation between public policing and private security companies, private security can act as a 'force multiplier' increasing security for all sections of society. On the other hand, a lack of co-ordination and co-operation can result in a gradual 'privatisation' of public policing, and hence an intensification and deepening of existing inequalities. $^{47}$

Fieldwork conducted in Kisumu gives initial suggestion that private security in Kenya is often uncoordinated and inadequate in exercising any community function. ${ }^{48}$ Seen in this way, the movement towards greater privatisation of security is part of a more general 'teleological reversal' in practices of institution building and civil society organisation, described by Jean Comaroff and John Comaroff as:

a move from increasingly rationalized, increasingly bureaucratized, increasingly elaborated regimes of rule toward ever more outsourced, dispersed, deinstitutionalized, constitutionally ordained governance - from political evolution, classically conceived, to political devolution. ${ }^{49}$

While nation-states in Africa have historically brought coercive capacities together in centralised hierarchies, ${ }^{50}$ innovations are increasingly taking an oppo-

45 Abrahamsen R and Williams MC, 'The politics of private security in Kenya', 32 Review of African Political Economy, 104/105 (2005), 425-431, 426.

46 Clapham's position as described by Baker, 'Protection from crime', 170.

47 Abrahamsen and Williams, 'The politics of private security in Kenya', 431.

48 Burbidge D, 'Urban trust in Kenya and Tanzania: Cooperation in the provision of public goods', 47 Canadian Journal of African Studies, 3, 2013, 465-482, 473-4.

49 Comaroff JL and Comaroff J, 'Law and disorder in the postcolony: An introduction'. Ch 1 in Comaroff $\mathrm{J}$ and Comaroff JL (eds), Law and disorder in the postcolony, The University of Chicago Press, Chicago, 2006, 3 .

50 Hills A, 'Policing Africa: Internal security and the limits of liberalisation', 25 International Review of 
site tack of disconnected institutionalisation relevant to particular stakeholders only. However, to look solely at how the organisation of security is structured is to miss the wood for the trees: the question is not how centralised or decentralised a security apparatus is (security has always been something decentralised in order to be centralised at the appropriate moment), but how inclusive the idea of the intended beneficiary is. It is here that Clapham's concerns re-emerge as relevant, less for normative evaluation of good versus bad security, as for asking whether security is being organised in line with community self-perceptions.

It has been well-explained by Jan Bachmann and Janna Hönke that attempts to recentralise security in Kenya have been made in response to the on-going threat of terrorism, and that the related policies have increased feelings of disenfranchisement among Kenyan Muslims, particularly on the country's east coast. ${ }^{51}$ The rift has been further manifested in poor relations between coastal governors and their county commissioner counterparts. ${ }^{52}$ However, while we normally look at this as a debate about institutional preference between those who want security centralised and those who want it decentralised, there is therefore this deeper question of for whom is security being restructured?

It is on this front that the devolved governments provided for in the 2010 Constitution point to new possibilities of congruence between community and State power. Because there is some idea of possible success in bringing the hidden capacities of the local into communicative cooperation with the security apparatus,$^{53}$ Kenya's radical devolution encourages debate that goes so far as to even test new forms of statehood.

\section{The situation under the 2010 Constitution}

The Fourth Schedule of the 2010 Constitution stipulates what functions are to be performed at the national level and what functions at the county level. It places police services and the courts firmly in the hands of National Government, leaving county governments without any such powers. ${ }^{54}$ In general, any

Law, Computers \& Technology, 1-2, 2011, 69-77; Cheeseman N, Lynch G, Willis J, 'Decentralisation in Kenya: The governance of governors', 54 Journal of Modern African Studies, 1, 2016, 1-35, 24.

51 Bachmann and Hönke, “Peace and security” as counterterrorism?', 107-8.

52 Cheeseman N, Lynch G and Willis J, 'Decentralization in Kenya', 25.

53 See, for example, Menkhaus K, 'The rise of a mediated state in northern Kenya: the Wajir story and its implications for state-building', 21 Afrika Focus, 2, 2008, 23-38.

54 Mutakha Kangu J, Constitutional law of Kenya on devolution, Strathmore University Press, Nairobi, 2015, 187. 
government functions not explicitly devolved by the 2010 Constitution remain within the purview of National Government. ${ }^{55}$

The only point of ambiguity in the Fourth Schedule with regard to policing is the allocation of the 'control of drugs and pornography' to county governments. This need not, however, form an area of confusion if by 'control' one understands powers such as enacting county legislation to manage drugs and pornography production or consumption, or the allocation of county government funds to awareness campaigns or other such non-police-specific endeavours. County-level legislation on drugs and pornography would therefore be enforced by national police services on a par with all Kenyan legislation.

Subsequent to promulgation of the 2010 Constitution, the Kenyan Parliament passed the National Police Service Act 2011 (NPSA), ${ }^{56}$ which in Section 41 created County Policing Authorities to, inter alia, 'develop proposals on priorities, objectives and targets for police performance in the county'; 'monitor trends and patterns of crime in the county'; and 'promote community policing initiatives' ( $\$ 41$ (9) (a-c)). In general, County Policing Authorities are 'a way for the community to get involved in policing at the local level. ${ }^{57}$ To some extent, the provisions meet with the Fourth Schedule, which provides county governments with powers of county planning and development, including collection of county-level statistics. Further, the Fourth Schedule requires county governments to engage in public participation for 'governance at the local level', making the promotion of 'community policing initiatives' in the NPSA something that could be subsumed under the general heading of public participation rather than contradict the categorisation of security as a national and not devolved function.

A County Policing Authority, as explained in the 2011 Act, is chaired by a governor or a member of the county executive committee appointed by the governor. The Authority is, additionally, comprised of county-level representatives of the National Police Service, National Intelligence Service and Directorate of Criminal Investigations; two members of the county assembly; the chairperson of the County Security Committee; and at least six other members appointed by the governor. In confirmation of the 2010 Constitution's demarcation of policing as a national function of Government, Section 41(13) of the NPSA states that 'nothing in this section shall authorize any Authority to interfere with -

The Constitution of Kenya 2010, Article 186 (3).

National Police Service Act 2011, No. 11A, Rev. Ed. 2014.

57 Release Political Prisoners Trust, 'Your guide to: The National Police Service Act, the National Police Service Commission Act and the Independent Policing Oversight Authority Act' (Jun 2012). 
$[\ldots]$ (b) the enforcement operations of the law against any particular person or persons; [...] (d) the operations of the [National Police] Service.'

On face value, the provisions of the NPSA therefore provide much less than what many governors asked for. In addition, a 2015 amendment to the statute removed the Section 41 (9) (c) provision for County Policing Authorities to be able to promote community-policing initiatives. In contrast to these limitations, governors were vocal in demanding that policing become a function of devolved government. In summary form, their reasons consisted in: 1) The role governors play and intend to play in reconciling inter-ethnic differences and conflict; 2) Recognition among governors of the priority security has for voters' perceptions of county government performance; and 3) Resentment at the way policing structures can and may be used by actors within National Government to circumvent local development plans, local aspirations for inter-ethnic harmony, or local enforcement of free and fair elections.

It can be speculated that a further, negative reason may exist: local control of security might allow governors to themselves manipulate political events and inter-ethnic relations to their advantage. The history of a centralised state in Kenya manipulating local elections through the arm of security is well established. ${ }^{58}$ Mai Hassan measures the cross-district effect of Daniel Moi's Government posting its own security officials in elections between 1992 and 2002 and finds that the appointed officials' ethnic similarity or difference to the local area significantly affected that area's vote share in favour of the President. ${ }^{59}$

Push-and-pull between security personnel and local political representatives over who is in charge locally has continued even more intensely with the advent of devolution. Neither the 2010 Constitution nor recent legislation has been able to establish a hierarchy that says which position has final authority in cases of overlap or dispute. Hassan explains:

Beginning in 2011, parliament debated legislation related to the PA Provincial Administration] that seemed to follow the constitution's spirit of weakening executive power. Early in the transition period, the PA was scrapped entirely and replaced with a new National Government administrative system, the National Administration (NA). [...] While Kenya's new National Government structure abolishes the province level (and by definition PCs [Provincial Commissioners]), the NA creates a new administrative post of County Com-

\footnotetext{
58 Branch D and Cheeseman N, 'The politics of control in Kenya: Understanding the bureaucraticexecutive state, 1952-78', 33 Review of African Political Economy, 107, 2006, 11-31.

59 Hassan M, 'The strategic shuffle: Ethnic geography, the internal security apparatus, and elections in Kenya'. Working paper, Nov 2014.
} 
missioner (CC) at the county level alongside the new elected county governors. [...] At first, the 2012 County Governments Bill specified that NA officials should report directly to the county governor and not the president. This was to ensure that the NA would "respect the system of devolved government" that the constitution mandated and would weaken executive power as the population envisioned. ${ }^{60}$

Contrary to these initial intentions, the finalised County Government Act $2012^{61}$ made no such comment on the relationship between county commissioners and governors, meaning that the legal relationship remains the same as stipulated in the 2010 Constitution - that each performs duties pertaining to their respective functions, concurrently over the same territory. The ambiguity this causes was anticipated to some extent in the 2010 Constitution's Sixth Schedule, which demanded the restructuring of the provincial administration to 'accord with and respect the system of devolved government' within five years of the 2010 Constitution's promulgation. Despite this requirement, National Government did not wish to restructure security in a way that would make governors look to be in ultimate control locally. On the other hand, a clear statement of the superiority of county commissioners would run the risk of creating an unwelcome level of opposition across the country towards the Jubilee Government. This seemingly irreconcilable tension means the status quo of concurrent activities and legal ambiguity is likely to endure in the medium to long term.

The only substantial move to break the deadlock was made in 2014 by President Kenyatta in a Public Service Commission policy note that affirmed the national superiority of county commissioners. For the National Government to achieve this manoeuvre without contravening the 2010 Constitution,

the answer lay in upgrading county commissioner salaries with the justification that, "[a]s the President's direct appointee, the powers of the office must not only be projected and felt through the office of the CC, it must be seen in the CC. Nobody in the county should have a second doubt as to who the Presidency's representative and head of National Government at the county is". ${ }^{.2}$

In contrast, governors instead proposed that they chair county security committees, which would deliberate directly over the use of police services in the county. Governors have included this in demands for a referendum on further

60 Hassan M, 'Continuity despite change: Kenya's new constitution and executive power', Democratization, 2013, 1-23, 14.

61 County Government Act 2012, No 17.

${ }_{62}$ Burbidge D, The shadow of Kenyan democracy: Widespread expectations of widespread corruption, Ashgate: Burlington, 2015, 48. 
devolution. ${ }^{63}$ Then Devolution Cabinet Secretary, Anne Waiguru, was, however, adamant that there should be no substantial devolution of security to the county level. ${ }^{64}$

Running in parallel to this disagreement, the Jubilee Government has attempted to implement, as part of its campaign promises, the 'Nyumba Kumi' (ten homes) initiative, an alternative type of decentralisation of security at the neighbourhood level. ${ }^{65}$ The plan has been vague and loose in implementation, with the general aim being to 'unite law enforcement, private individuals and businesses in a nation-wide effort to reduce crime' by 'bringing Kenyans together in clusters defined by physical location. ${ }^{66}$ Despite its flaws, Nyumba Kumi is openly tabled as an alternative to demands for the devolution of security, with the programme's national coordinator Joseph Kaguthi falsely deploying devolution terminology, stating, '[w] 're trying to devolve security to the lowest levels and raise levels of security education among the people. ${ }^{37}$ In a politically contested environment, apart from contestation over whether to bring security to the local level, therefore, strong divisions exist over how.

\section{The political situation: Four case studies}

The preceding analysis shows that while there is nominal clarity over security not being a devolved function, historically the Government has struggled to provide security evenly across the country. This creates political tensions where local stakeholders feel the need to advocate for a security apparatus more in line with community self-perceptions. Because the very performance of security services further depends on cooperative and communicative relations with the population, the implementation of constitutional provisions has struggled to adapt to local community diversities. Under these conditions, it is impossible to fully understand the developments at play without direct engagement with county-level case studies reflective of nationwide diversity. The current section therefore provides assessment of the security situation and relevant political relationships in the four counties of Lamu, Garissa, Machakos and Isiolo. The case studies are expressly chosen to best outline the wide variety of relations between county security officials and county-level politicians across the country.

\footnotetext{
63 Muraya J, 'Do we need to devolve security functions?', Capital FM News, 11 Aug 2014.

64 Onyango P, 'Security will not be devolved, says CS Waiguru', Standard, 23 Apr 2015.

65 Nyumba Kumi FAQs. http://www.nyumbakumisecurity.com/index.php/about.

66 Analo T, 'Crime, distrust in police lie in wait for "Nyumba Kumi"”, The East African, 25 Oct 2014.

67 Muchangi J, "Nyumba Kumi” is not a political project - Kaguthi', The Star, 9 Jun 2014.
} 


\subsection{Lamu County}

Governor

Percentage of votes won above $2^{\text {nd }}$ place gubernatorial candidate

\author{
County Commissioner
}

Issa Timamy

(United Democratic Forum Party; Swahili ethnicity)

4.5 percent $^{68}$

(Deputy) Fredrick Ndambuki

(currently acting County Commissioner; Kamba ethnicity)

\section{Majority Party in County Assembly Orange Democratic Movement}

Between 15 and 17 June 2014, Al-Shabaab killed approximately 68 people in the areas of Majembeni, Mpeketoni and Poromoko of Lamu County as part of a general retaliation against Kenya's 2011 intervention into Somalia. During early speculation over the source of the attack, President Kenyatta declared that it was 'politically motivated ethnic violence against a Kenyan community [and] not an Al-Shabaab terrorist attack'. ${ }^{69}$ Put briefly, there is ongoing concern over the interconnection between inter-ethnic relations and terrorism in Lamu, which means Kenyatta's statement, though fundamentally incorrect, ${ }^{70}$ reflects wider concerns over title deeds and inter-ethnic disagreement surrounding Kikuyu settlements in Lamu. ${ }^{71}$

These political divisions, and the President's problematic framing of the situation, led Governor Issa Timamy to be placed under trial for involvement in the terrorist activities that targeted Kikuyu around Mpeketoni. ${ }^{72}$ Although charges were subsequently dropped, the case represents a harrowing example of direct intervention by National Government into devolved government on grounds of security. The particular vulnerability of Governor Timamy is in part due to the ethnic diversity of his county, which renders his electoral position

68 Independent Electoral and Boundaries Commission, 'Summary of results for governor, 2013', 2013. http://www.iebc.or.ke.

69 Capital FM News, 'Lamu attacks political, not terrorism - Uhuru', 17 Jun 2014.

70 Ochami D, 'Al-Shabaab releases chilling video about Mpeketoni attack', Standard, 9 Mar 2015.

71 Butime H, 'Unpacking the anatomy of the Mpeketoni attacks in Kenya', Small Wars Journal, 23 Sep 2014.

72 Al-Jazeera, 'Kenya governor tried over Lamu massacres', 16 Jul 2014. BBC News, 'Kenya attack: Charges dropped against Lamu’s Timamy’, 10 Sep 2014. 
tenuous and adds controversy over the ethnicity of appointed security officers. ${ }^{73}$ The single largest ethnic group in Lamu County is the Swahili, who constitute 30 percent of the local population. Recent analysis estimates that the Governor, who is also Swahili, has appointed a County Executive Committee of 70 percent Swahili composition. This makes the Lamu County Government the single most over-representative of its local ethnic majority among all county governments of Kenya. ${ }^{74}$ Thus, combined justifications of National Government intervention on grounds of national security, land distribution and the construction of a port - all three of which are assigned functions of the National Government mean the County Government is increasingly beholden to the will of the political centre and unable to influence security operations so as to be responsive to local youth radicalisation. As such, governors frequently cite Lamu as evidence for the need to devolve security functions across the country. ${ }^{75}$

\subsection{Garissa County}

\section{Governor}

Percentage of votes won above $2^{\text {nd }}$ place gubernatorial candidate

\section{County Commissioner}

\author{
Nathif Adan \\ (Wiper Democratic Movement- \\ Kenya; Somali ethnicity)
}

3.1 percent $^{76}$

Njenga Miiri

(suspended; Kikuyu ethnicity)

Majority Party in County Assembly Orange Democratic Movement

Garissa County stretches on its eastern side across the Kenya-Somali frontier, and to its south borders Lamu County. The porous and contested nature of the Kenya-Somali border, ${ }^{77}$ combined with growing politicisation of the identity of ethnic Somalis across the country, ${ }^{78}$ renders Garissa a charged environment for the growth of terrorism and cross-border raids. Despite all this, the County

\footnotetext{
73 Beja P, 'Lamu police transfers spark ethnic vibe among leaders and activists', Standard, 24 Aug 2014.

74 Burbidge D, 'Democracy versus diversity: Ethnic representation in a devolved Kenya'. Working paper, Princeton University, 2015, 17.

75 Korir W, 'Governors want security devolved to avoid Lamu scenario', News 24 Kenya, 21 Jul 2014.

76 Independent Electoral and Boundaries Commission, 'Summary of results for governor, 2013'.

77 Thompson, Conflict in the Horn of Africa.

78 Burbidge, 'The Kenyan State's fear of Somali identity'.
} 
has only one Kenya Police and one Administration Police office. ${ }^{79}$ The population of the County is 79.6 percent of Somali ethnicity, which is also the ethnicity of Governor Nathif Adan and, it is estimated, his entire County Executive Committee. ${ }^{80}$ The County's proximity to Somalia means the relationship between security and devolved government is tenuous and under heightened scrutiny. In 2014, Deputy President William Ruto stated that the National Government could suspend the Marsabit County Government - which is in a similar situation to Garissa - over failures to provide security ${ }^{81}$ Rivalry had been brewing between the Governor and a local Member of Parliament (MP), which 'followed the lines of long-standing tensions between Gabbra and Boran, leading to an outbreak of violence. ${ }^{82}$ National Government suspension of a county government can take place under the powers established in Section 192 of the 2010 Constitution. The provision leaves governors of harder-to-reach areas of the country somewhat at the mercy of National Government sentiment, even though throughout their term in office governors have no constitutional power to affect directly how security is deployed in their areas. In September 2014, the Garissa regional passport office was closed by order of the Director of Immigration, Major-General (Rtd) Gordon Kihalangwa, despite local outcry. ${ }^{83}$

On 2 April 2015, 147 members of Garissa University College were killed in a raid by Al-Shabaab, widely reported on by international media. In contrast to the politicisation of the Lamu County Government, the National Government responded with scrutiny of its security forces operating in the County, in a way that was more appropriately self-critical and reflective. Seven high-ranking police officers were suspended following an inquiry into the failed security response. ${ }^{84}$ Further, Interior Secretary Joseph Nkaiserry also suspended Ernest Munyi, North Eastern Regional Coordinator, and Njenga Miiri, County Commissioner of Garissa ${ }^{85}$ Miiri was previously County Commissioner of Lamu, though there are conflicting accounts over whether he was in office in Lamu over the course of the Mpeketoni attacks. The BBC described him as such, though local media sources have it that Miiri was immediately deployed to replace County Commis-

\footnotetext{
79 International Crisis Group, 'Kenya's Somali north east: Devolution and security'. Crisis Group Africa Briefing No. 114, Nairobi/Brussels, 17 Nov 2015, 12.

Burbidge, 'Democracy versus diversity', 16.

Obala R, 'Senator defends William Ruto over county remarks', Standard, 20 Jan 2014.

Cheeseman N, Lynch G, Willis J, 'Decentralization in Kenya', 29-30.

Hajir A, 'Immigration halts services amid outcry', Daily Nation, 14 Sep 2014.

BBC News, 'Kenya suspends police over Garissa “security failings”" 21 Apr 2015.

Nairobi News, 'Nkaissery suspends Garissa security chiefs', 21 Apr 2015. Hassan S, 'Garissa gets new police bosses as IG Boinnet reshuffles county commanders'. Nep Journal, 23 Apr 2015.
} 
sioner Stephen Ikua as the scale of the attacks became known, which is why his appearance at many media events following the Mpeketoni attacks made some outlets describe him as Lamu County Commissioner during the events. ${ }^{86}$ This complication notwithstanding, Miiri's fraught reputation, together with controversy over his comments that the Internally Displaced Persons produced by the Lamu attacks were mostly 'impostors', ${ }^{87}$ helped National Government see a need to reform security provision in Garissa following the university killings.

As a report by International Crisis Group explains, following the attacks 'north-eastern leaders proposed many recommendations directly to the President, notably appointing an overarching regional coordinator, replacing the three county commissioners [of Mandera, Wajir and Garissa] and deploying more security forces, mostly drawn from the local population. ${ }^{88}$ Initial resistance to such proposed changes was made by National Government over fears that it would set a precedent of allowing synergy between devolved structures of governance and national security provision. Instead, Kenya's north-east is preferred to be framed by National Government as exceptionally lawless, in fear of the region's history of secession demands. ${ }^{89}$ The reality, however, is that by replacing security officials with those more locally attuned, positive in-roads have been made in quelling Al-Shabaab.

4.3 Machakos County

Governor

Percentage of votes won above $2^{\text {nd }}$ place gubernatorial candidate

County Commissioner

Majority Party in County Assembly
Alfred Mutua

(Wiper Democratic Movement-

Kenya; Kamba ethnicity)

45.0 percent $^{90}$

Ann Gakuria (Kikuyu ethnicity)

Wiper Democratic Movement-

Kenya

86 See BBC News, 'Kenya suspends police over Garissa "security failings"”; Mayoyo P, "Top officers moved in bid to bring calm', Daily Nation, 17 Jun 2014. Beja, 'Lamu police transfers spark ethnic vibe among leaders and activists'; Bocha G, 'Lamu leaders hold peace meeting following attacks', Daily Nation, 16 Jul 2014.

87 Praxides C, 'Lamu IDPs not genuine, says Miiri', The Star, 26 Aug 2014.

88 International Crisis Group, 'Kenya's Somali North East: Devolution and security', 13.

89 International Crisis Group, 'Kenya's Somali North East: Devolution and security'.

90 Independent Electoral and Boundaries Commission, 'Summary of results for governor, 2013'. 
Touted as one of the most entrepreneurial and successful cases of devolution, Machakos County has focused on numerous highly visible public service expansions since the 2013 election. Under Governor Alfred Mutua, the County Government has treated security in a way almost equivalent to any other area of county-level public service provision. This has meant organising procurements tailored to suit the needs of security and police services that operate in the county, and maximising the visibility of these procurements as brought about by the County Government. Apart from purchases of 500 CCTV cameras and 40 police dogs, in a highly publicised event, Governor Mutua unveiled 120 police cars for use within the county. ${ }^{91}$ Subsequently, Mutua financed the construction of houses for security officers. ${ }^{92}$

This direct involvement in security provision is in flagrant disregard of the 2010 Constitution's demarcation of security as a function of National Government. However, the slickness of Mutua's media campaign has meant almost no coverage or debate over its unconstitutionality. ${ }^{93}$ Indeed, KTN, one of the most respected news channels in Kenya, avoided any admonishment and instead described the purchases as meaning 'Machakos County could have a big head start in security compared to the other 46 counties'. ${ }^{94}$ Mutua justified the purchases by framing security provision as a duty that all Kenyans should be involved in, emphasising that 'security is not a National Government or county government issue only. I am asking all of us to discourage crime by not buying goods they know or suspect are stolen and also to identify and report criminals in their neighbourhood to the authorities'. ${ }^{95}$ In this way, he tactfully employed "nyumba kumi" vocabulary to give the impression of promoting National Government agenda. Some queries were raised by the Auditor General over the procurement processes of vehicles by the County Government, ${ }^{96}$ however, giving the specific recommendation that '[s]ince the duty of security provision is primarily of the National Government, the purpose for which the ninety one (91) vehicles were

${ }^{91}$ KTN News, 'Machakos County governor Dr Alfred Mutua unveils 120 police cars to enhance security', 30 Jan 2014. https://www.youtube.com/watch?v=MIORr43gtQI.

92 Counties News, 'Machakos: Government builds houses for security officers and health workers', 15 Jul 2015.

93 The Director of Public Prosecutions did, however, investigate a corruption claim on the purchasing of vehicles. Mbuthia E, 'Director of Public Prosecutions clears Kingi, Kavuludi of graft claims', Business Daily, 15 May 2015.

94 The Director of Public Prosecutions did, however, investigate a corruption claim on the purchasing of vehicles. Mbuthia E, 'Director of Public Prosecutions clears Kingi, Kavuludi of graft claims'.

95 Odalo B, '120 security cars for Machakos County', Daily Nation, 30 Jan 2014.

96 Njagih M, 'Auditor paints a different picture of Machakos County', Standard, 18 Feb 2014. 
provided to the police should be clearly stated. ${ }^{97}$ However, the concerns only led to further requests for documentation, ${ }^{98}$ not any fundamental questioning of the constitutionality of a county government operating through a memorandum of understanding with the police force.

In terms of county government budgeting, the purchases were made as part of a labelled 'Machakos Comprehensive Security and Emergency Program'. 99 Vehicles came already painted; their labelling 'Police / Machakos County' gives Mutua credit in the eyes of voters whenever the cars are on patrol. Machakos Senator Johnstone Muthama has been a frequent critic of Mutua on this and many other issues. ${ }^{100}$ However, Mutua has so far remained immunised from such criticism due to his positive media profile and fruitful relations with County Commissioner Gakuria, who stands to benefit in terms of greater resources put at her disposal for the work of policing. Gakuria's firm relationship with Mutua was publicly heralded by Johnstone Kavuludi, Chairperson of the National Police Service. The good relations Mutua enjoys are completed by his strong links with the incumbent Jubilee Coalition National Government. From 2004 to 2012, Mutua was Government Spokesperson and Public Communications Secretary, and retains a highly visible presence in national media.

\subsection{Isiolo County}

\author{
Governor
}

Percentage of votes won above $2^{\text {nd }}$ place gubernatorial candidate

County Commissioner
Godana Doyo Adhi

(United Republican Party; Borana ethnicity)

6.6 percent $^{101}$

Wanyama Musiambo

(Luhya ethnicity);

George Natembeya

(Luhya ethnicity)

Majority Party in County Assembly United Republican Party

\footnotetext{
97 Republic of Kenya, 'Report of the Auditor-General on the financial operations of Machakos County Executive for the Period 1 July 2013 to 30 June 2014', 2014, 14.

98 Ongiri I, 'Machakos County to be probed for allegedly flouting tender rules', Daily Nation, 4 Jul 2014.

99 Government of Machakos, 'Machakos comprehensive security and emergency program', 2015.

100 Makana F, 'Governor Alfred Mutua to face charges over purchase of 16 vehicles', Standard (23 Sep 2016).

101 Independent Electoral and Boundaries Commission, 'Summary of results for Governor, 2013'.
} 
Historically, Isiolo has suffered frequent and sometimes ruinous inter-communal violence. The County hosts the Borana, Gabra, Meru, Samburu, Somali, and Turkana ethnic groups - the single largest group being the Borana (at 36.9 percent), followed by the Somali. ${ }^{102}$ Violence was particularly intense between 2009 and 2012, with causes including: political campaigns oriented towards ethnic voter bases; land disagreements, removals and elite-led purchases; cattle rustling; and security vacuums leading to pre-emptive inter-communal violence through the proliferation of small arms.

Despite these trends, initial interaction between security services and the County Government promoted leadership sensitive to the needs of local communities. The Governor of Isiolo, Godana Doyo Adhi, is of Borana ethnicity, and came to office together with running mate Mohamed Guleid, a Somali. As representatives of the two largest groups of the County, the alliance promoted inter-ethnic solidarity between the two communities. Further, the County Government enjoyed strong and supportive relations with County Commissioner, Musiambo, who as a Luhya is not of any of the ethnic communities dominating politics in the County. Behind the scenes, Governor Doyo and Deputy Governor Guleid facilitated ongoing consultations with elders of locally dominant tribes, which helped foster some sense of inclusion and collaboration. ${ }^{103}$ The County Government openly describes security as its number one priority, which links also with its aspiration to act as a key hub for the transport of oil and goods to the Lamu port as part of Kenya's Vision 2030.

The attempt to guarantee security for local residents has, however, been severely challenged by a boundary dispute with Meru County to the south. The boundary dispute involves a complicated plethora of competing claims, ranging from land disputes surrounding the town of Isiolo, access to sand extraction for construction, access to grazing land for cattle, and competing demands over the location of the proposed airport. The business and livelihood interests that surround these issues have encouraged a stoking of political rhetoric among Isiolo and Meru politicians, and the mobilisation of residents and youth groups. In October 2015, clashes resulted in six deaths, with violence erupting again only a few days later in protest at the death of a motorbike taxi operator, which mainly involved confrontational exchanges between members of the Borana and Meru

\footnotetext{
102 Kenya National Bureau of Statistics, Socio-economic atlas of Kenya: Depicting the national population census by county and sub-Location, Kenya National Bureau of Statistics, Nairobi, 2014, 56-7.

103 Scattered instances of violence nevertheless endured. See The Star, 'Inter-tribal conflict kills eight in Isiolo', 12 Nov 2014.
} 
ethnic communities. ${ }^{104}$ The ensuing chaos involved the looting of shops and blocking of the Isiolo-Nanyuki highway, and was only brought to a close with the deployment of the military's $78^{\text {th }}$ Tank Battalion, stationed nearby. ${ }^{105}$ In response, the Member of County Assembly for Bula Pesa, Moses Kithinji, Chief Officer for Trade, Hudson Kinyua, and Ward Administrator for Bula Pesa, Witherford Mwirigi, were arrested under charges of inciting youth to violent protests. ${ }^{106}$

In the first half of the political term, relations were therefore broadly speaking positive between Isiolo politicians and the County Commissioner. However, with the entry of new County Commissioner, George Natembeya, these relations have run into difficulty. Commissioner Natembeya has made explicit a shoot-to-kill policy towards those in the County carrying arms illegally, ${ }^{107}$ which comes across as high-handed, presumptuous and out of touch. Natembeya demonstrated some support for the aims of Isiolo politicians by arresting 40 Meru protestors in April 2016, who were attempting to block contractors from completing a water supply project for Isiolo town. ${ }^{108}$ However, relations deteriorated again when a widely reported complaint about the standards of health care provision in Isiolo's referral hospital prompted Commissioner Natembeya to carry out an inspection of the facility, which Governor Doyo interpreted as something of an encroachment on County Government duties and a shaming of County Government performance. Doyo confronted Natembeya in the hospital and ejected him, even though commissioners have as among their legitimate duties visiting and inspecting government-owned buildings. ${ }^{109}$ When elders of Isiolo reacted to the confrontation, they stressed a need for 'clear separation of powers between the County Government officials and representatives of the National Government'. ${ }^{110}$

104 News sources conflict in their reports of whether the killed motorbike operator belonged to the Meru or Borana ethnic communities, and which community started the street-level disruptions. See Chebet V and Kimanthi K, 'Violence rocks Isiolo as boda boda operators clash', Daily Nation, 30 Oct 2015. Muriuki B, 'Communities fight over boda-boda rider', Kenyans.co.ke, 30 Oct 2015. Salesa H, 'Communities clash at Isiolo-Meru border after killing of boda boda rider', The Star, 30 Oct 2015.

105 Abdille A, 'Kenya: Development, county governments and the risk of 2017 election violence'. International Crisis Group, 7 Apr 2016. http://blog.crisisgroup.org/africa/kenya/2016/04/07/kenyadevelopment-county-governments-and-the-risk-of-2017-election-violence/.

106 Muriuki B, '3 senior officials arrested over Isiolo violence', Kenyans.co.ke, 1 Nov 2015.

107 Daily Nation, 'Isiolo County commissioner George Natembeya reaffirms shoot-to-kill directive’, 18 Nov 2015.

108 Isiolo Wire, '40 people arrested after they blocked Isiolo-Nanyuki road at Maili Saba to force Government abandon project to pump water to Isiolo’ (20 Apr 2016).

109 Jebet V, 'Isiolo county boss storms referral hospital to eject official', Daily Nation, 8 Jul 2016.

110 Wambui E, 'Isiolo elders urge residents to shun violence, protests', Citizen, 20 Jul 2016. 


\section{Conclusion}

There is a clear separation of powers between security services and local politics according to the 2010 Constitution: governors are not to manage law and order. The problem comes with the history of an uneven security presence across Kenya, meaning that, in fact, it is next to impossible for governors to ignore the security concerns of their local residents. Alongside advocacy for constitutional reform that would give them greater say over security provision, therefore, governors are active in the politics surrounding local security provision. On the one hand, this tends to bruise relations with county commissioners and National Government because governors easily politicise matters and can often be in support of one particular ethnic community at the expense of others. On the other hand, however, the new situation is forcing security services to at least acknowledge local diversities and the value of more community-inclusive law and order strategies.

County governments are acting as mini-states that are in part defined by the legitimate use of physical force within their mini-territories. While Weber had in mind a sovereignty that rests in bureaucratic centralisation through the nationstate, Kenya's county governments present a new and hitherto untested model of contained governance that is more in line with community self-perceptions. Of course, for counties of rivalrous ethnic politics, a yearning for harmonious community-led security is a mirage. It looks backward to Kenya's history of zoned security where freedom of movement was heavily restricted, now incompatible with the dual rural-urban lifestyles of modern Kenya. Nevertheless, there is something unspeakably progressive about a constitution that retains flexibility; local political diversities may be matched by flexibility in security's implementation. 
